Dr. Johannes Steizinger

University of Vienna

This is the penultimate draft of a chapter that has been published in The Emergence of Relativism: German Thought from the Enlightenment to National Socialism, edited by M. Kusch, K. Kinzel, J. Steizinger, and N. Wildschut, Routledge (London, New York) 2019, 233-251.

\title{
National Socialism and the Problem of Relativism
}

\section{Introduction}

The aim of this chapter is to clarify the meaning and the use of the concept of relativism in the context of National Socialism (NS). This chapter analyzes three aspects of the connection between relativism and NS: The first part examines the critical reproach that NS is a form of relativism. I analyze and criticize the common core of this widespread argument, which is developed in varying contexts, was held in different times, and is still shared by several authors. The second part investigates the ideological debate among Nazi philosophers themselves concerning whether NS is indeed a form of relativism. I focus on the epistemological consequences of Nazi anthropology and analyze both its relativistic tendencies and the strategies used to reject relativism. In contrast to the received view, I argue that Nazi philosophers attempted to overcome both absolutism and relativism. The third part investigates the academic debate on relativism during NS, using the example of the prize question on relativism that was announced by the Prussian Academy of Science in 1936. By examining the academic approaches to the problem of relativism, I also address the question of how broader philosophical debates were related to the core of Nazi ideology. Academic philosophers took the selfunderstanding of Nazi philosophers seriously. They saw the shared aim of overcoming relativism as an opportunity to collaborate with NS. The brief conclusion summarizes the findings of the chapter. I conclude that, in the context of NS, critics, ideologists, and academics understand and use the concept of relativism in the same way. 


\section{The Received View: NS as Relativism}

The connection between relativism and NS is often used as a critical argument against both. The weakest form of this argument runs as follows: Anti-relativists claim that relativism is motivated by the conviction that there are many radically different, yet equally valid epistemic or moral systems. This equal validity claim ties the relativist to a strong form of tolerance: Confronted with a conflicting epistemic or moral system, the relativist has to concede that the other agent is equally justified in her epistemic or moral beliefs. Hence, relativism does not provide us with the normative resources to criticize irrational views such as Nazi racism. We need a normative universalism to confront racist ideologies (Böhler 1988, Tugendhat 2009, Kellerwessel 2014). Such systematic claims are often supported by the historical argument that the relativism of post-Hegelian philosophy indeed paralyzed the moral consciousness of German intellectuals during Weimar Republic. Their inability to mobilize universal moral principles is regarded as a reason for the rise of NS (Apel 1988). This historical argument can take a stronger form. Some authors argue that the relativism of post-Hegelian philosophy is a prerequisite of Nazi ideology. Here, Nazi ideology is classified as a radical kind of relativism that emerges from the general path of German philosophy after Hegel (Böhler 1988, Wolin 2004, Kellerwessel 2014).

The identification of NS with relativism has a long history and is still popular. The most influential account stems from Georg Lukács (1885-1971) who held a Hegelian Marxism when he published his polemical treatise Die Zerstörung der Vernunft (The Destruction of Reason) in 1954. The Neo-scholastic Josef de Vries (1898-1989) confronted Nazi philosophers with the charge of relativism already in the 1930s (de Vries 1935a, 1935b). Recently, proponents of discourse ethics combined their reading of NS as relativism with the warning that postmodernism represents a similar kind of relativism and could thus have devastating moral consequences (Apel 1988, Böhler 1988, Kellerwessel 2014).

The argument equating NS with relativism is therefore developed in varying contexts like Marxism, Catholicism and discourse ethics. The different versions share, however, a common core: Most of these critical anti-relativists embed their identification of NS with relativism in a broader claim about the nature of philosophy. They argue that philosophy has to be based on reason and requires an orientation to a kind of absolute truth. Moreover, they defend the possibility of objective knowledge about reality and believe in a universal foundation of morality. These systematic convictions are usually connected with a claim about the historical 
development of post-Hegelian philosophy. The critical anti-relativists accuse especially historicism and Lebensphilosophie (philosophy of life) of having advocated a "dangerous" relativization of truth, knowledge, and values. On this view, the "relativistic nineteenth century" created a philosophical framework that enabled the flourishing of irrational beliefs, arbitrary maxims, and nihilistic attitudes. Ideologies such as NS are regarded as the ultimate step of the "destruction of reason" (Lukács 1954, see also de Vries 1935a, 1935b, Lieber 1966, Apel 1988, Böhler 1988, Wolin 2004).

Recent accounts highlight the destruction of moral rationality by the alleged relativism of Nazi racism. They read Nazi ideology as biological determinism that attributes mutually exclusive sets of values to the alleged races. The particular values of a race are chosen arbitrarily and are understood only instrumentally, since their realization should ensure the survival and flourishing of the respective race. The alleged racial hierarchy has no normative foundation and is thus completely arbitrary too. This "extreme relativism" of NS is defined as the opposite to moral rationality and is considered as an attack against philosophy itself

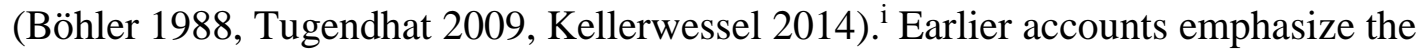
opposition of NS to rationality in general. Lukács characterizes Nazi ideology as a modern myth that is nothing more than demagogic and nihilistic propaganda designed to deceive the population. Here NS is portrayed as the consequence of the decay of philosophy that was caused by relativism. Following Lukács, Lieber (1923-2012) explicitly defines NS as the "end of philosophy" (Lieber 1966: 93). ${ }^{\text {ii }}$

There are several reasons why the argument equating NS with relativism is problematic: First, the argument rests on strong background assumptions about the nature of philosophy and morality. Most presentations of the argument equating NS with relativism take absolute standards for granted and thus lack a proper justification of their default position. This is problematic because the critical anti-relativists hold conflicting views such as Marxism, Catholicism, or discourse ethics: their versions of absolute truth, objective knowledge, and universal values contradict each other.

Second, the concept of relativism is used only in a pejorative sense. Relativism is often identified with the lack of what rationality consists in.

Third, the pejorative use of the concept of relativism makes the historical argument problematic. There are hardly any philosophers who actually held the kind of relativism that is presented by the critical anti-relativists. Their historical accounts are generally uncharitable and lack philological scrutiny. Representatives of historicism and Lebensphilosophie are used as mere whipping boys. The one-sided portrayals of Dilthey (1833-1911) or Nietzsche (1844- 
1900) as typical relativists ignores or misrepresent their actual engagement with the problem of relativism. ${ }^{\text {iii }}$

Fourth, the argument equating NS with relativism rests on a poor understanding of Nazi ideology. Recent historical research shows that Nazi ideology can neither be reduced to deceitful propaganda nor to simple biologism. The mere fact that many professional philosophers contributed to Nazi ideology should already make us doubt the equation of National Socialism with "the end of philosophy." The critical anti-relativists invoke a normative notion of philosophy that does not correspond to the historical reality.

Fifth, and most importantly, most critical anti-relativists do not consider the actual debate about relativism in the context of NS. Since Nazi philosophers were accused of being relativists by their contemporaries such as de Vries (1935a, 1935b), they engaged seriously with the problem of relativism. The actual contributions of Nazi philosophers to this debate reveal their self-understanding and are therefore an important source for defining the relation of NS to relativism. The critical analysis of this engagement also shows us the meaning and the use of the concept of relativism in the historical context. In the next section, I examine this historical context.

\section{The Ideological Debate: NS versus Relativism}

Nazi ideologues and philosophers were confronted with philosophical problems such as relativism because of the comprehensive character of their political claims. NS considered itself as a political revolution that realizes a new image of the human. Recent historical research confirms the self-understanding and contemporary perception of NS as a weltanschauliche Bewegung (ideological movement; see, e.g. Kroll 1998, Szeynmann 2013, Raphael 2014). ${ }^{\text {iv }}$ These nuanced approaches to the ideological dimension of NS suggest a new understanding of its structure and explain long ignored phenomena like the high degree of self-mobilization of German academia (Sluga 1993, Wolters 1999, Raphael 2014).

Nazi ideology has to be seen as a set of basic beliefs and convictions which offered much scope for interpretation. Although key concepts like race had to be accepted as guidelines of thinking and acting, different interpretations of such ideological core elements coexisted and competed even in the inner circle of Nazi leadership. Put shortly, since there was no unified and mandatory ideological system, the well-known policracy of Nazi government was accompanied by the polycentrism of Nazi ideology. ${ }^{\mathrm{v}}$ Nevertheless, it does not follow from this lack of a dogmatic version that Nazi ideology was nothing but a chimera. The 
"combination of fluidity and flexibility with a set of convictions and core arguments" (Raphael 2014: 74) shows, instead, that a political ideology works best as controlled plurality. While demanding a general appeal and specific direction, the Nazi worldview remained open to individual and contextualized interpretations. Take the example of the concept of race: once you had accepted its key role for understanding whatever phenomenon interested you, you could engage in the heated debate on its meaning and significance. The range which was developed in the ideological writings of political leaders reached from bluntly biological conceptions (e.g. Darré [1902-1946]) to metaphysical interpretations of race (e.g. Rosenberg [1893-1946)). Such obvious tensions were never removed and created the impression that NS was always in need of further explication. The crudity of Nazi ideology was a key reason for the intensive collaborations of scholars.

Philosophers in particular took up the task of elaborating, justifying, and explaining what NS truly is. There was a veritable quest for the officially accepted philosophy of NS in which representatives from most camps of German philosophy participated. Many German philosophers thus welcomed NS and attempted to show its philosophical significance. They put their philosophy into political service. The gesture of general agreement with the political change and the willingness to work in the direction of the leader (dem Führer entgegenarbeiten) were even more widespread. ${ }^{\mathrm{vi}}$

In the following, I concentrate on a specific philosophical interpretation of NS and its claim to realize a new concept of humanity. A number of philosophers welcomed NS because of its political break with the humanist tradition. Philosophers including Alfred Baeumler (1887-1968), Ernst Krieck (1882-1947), and Erich Rothacker (1888-1965) defined their own task as establishing a new conception of humanity in the realm of theory. Thus, anthropology became a paradigmatic way to understand NS philosophically. This strand of Nazi philosophy was politically relevant because its key motifs were shared by an important representative in the inner circle of Nazi leadership: Alfred Rosenberg. ${ }^{\text {vii }}$ My examination focuses on the radical views of Rosenberg, Baeumler, and Krieck who were often attacked because of their alleged relativism (see, e.g. de Vries 1935a, 1935b).

Their emphasis on the anthropological significance of NS was motivated by a strict rejection of universal concepts of humanity. Rosenberg, Baeumler, and Krieck argued that universalist doctrines provided only abstract accounts of human life which did not capture its actual reality. They concluded that such approaches were false and, moreover, often suggested that all universal concepts of humanity are deceitful fictions. Universalist claims were defined as purely ideological mechanisms that should hide the imperialist aspirations of certain actors 
on the world stage. From a Nazi perspective, universalists suggested that a certain way of life is the only way of life and thus threatened the identity of all other people. This line of thought was often combined with a critique of modern culture. Many Nazi philosophers believed that in the wake of modernity many people, in adapting to Western culture, lost their particular identity. The humanist tradition was accused of hiding the fact that a particular Western form of being human claimed to be the only form of being human. ${ }^{\text {viii }}$

The idea of an "endangered identity" was not only a major motif of the Nazi critique of modernity, but it was also the starting point of a specific political anthropology. The invocation "Remember who you are" (Baeumler 1934a: 6) was a key formula of Nazi ideology which also propagated a specific solution to the problem of identity: "Race always tells us what we are" (Baeumler 1943a: 93). Here, the "racial awakening" of NS was defined as a political response to the alleged identity crisis of humanity in modernity. From a Nazi perspective, identity always meant collective identity and the latter was constituted by belonging to a community. Moreover, an individual belonged to a community by birth, and hence the identity of a person was a fixed property. Since both the body and the thought of an individual was shaped by descent from a particular group, belonging to this community became the essential and sole dimension of a person's identity. This sublation of individuality to community was a key motif of Nazi ideology in general.

Most Nazi philosophers were convinced that race is an essential property of humans that structures the world. They presented this "racial particularism" as the anthropological alternative to the "raceless universalism" of the humanist tradition. ${ }^{\text {ix }}$ The basic motifs of their racist anthropology were: From the "racial standpoint", communities are the sole agents of human life. Communities are defined as distinct entities with natural and historical components: "blood and soil" ("Blut und Boden"). Race usually represents the natural component and is tantamount to a fixed type that could not be changed. But the racial types have to be realized in history by "breeding” (“Zucht”) and "fighting” (“Kampf”). Most Nazi philosophers regard history as nothing but the struggle of races for their self-realization as particular communities, i.e. as Völker. Thus, a community has to assert itself against all forms of otherness to become and remain the Volk it is: it has to be itself physically as well as spiritually, inwardly as well as outwardly. Each race has a spiritual center that is expressed in the cultural systems of its communities, including morality, science, and philosophy. The establishment of a "type-appropriate" ("artgerechte") culture is an essential part of the selfrealization of a community. The distinction between communities comes in degrees: communities from the same racial type are akin to each other and may understand each other 
on a basic level. Some races are, however, totally alien to each other and hence lack any mutual understanding.

Baeumler and Krieck drew epistemological consequences from the völkisch particularism of their political anthropology. Their epistemologies revealed the relativistic tendency of their thinking most clearly. They considered the community as the only source of epistemic authority and rejected all aspirations to universality, objectivity, and absoluteness in the realm of knowledge. As Krieck put it: "For us there is only one truth - but it is only for us." (Krieck 1934a: 17, see also 1936a: $1 \mathrm{f}$.) The belief in the normative authority of community gave rise to a radically socialized and politicized concept of knowledge. Baeumler and Krieck emphasized the revolutionary character of their social and political epistemology. The dismissal of universal values, objective knowledge, and absolute truths as mere fictions was presented as a radical renewal of philosophy from a Nazi perspective. The key motifs of its epistemological core were:

a) Dependence ("Gebundenheit"): The basic conviction of Nazi epistemology was that all knowledge is dependent on the social and historical context in which it emerges. Even scientific knowledge is bound to the racial-völkisch community that discovers and preserves these insights under specific circumstances. Consider Krieck's concept of science: He defended the idea that there is a distinct "German science" (deutsche Wissenschaft) and regarded its claims as nothing but "the expression, the impact of the German character and essence" (Krieck 1938: 28). ${ }^{\mathrm{x}}$ This radical form of dependence reduced all kinds of knowledge to the racial-völkisch framework that was developed by Nazi anthropology.

b) Limitation ("Begrenztheit"): Krieck also emphasized that the insights of "German Science" can only be understood within the German community. Moreover, he defined the borders of a community as the limits of the validity of its claims (Krieck 1938: $126 \mathrm{f}$.). Krieck assumed that our knowledge is constrained by the racial-völkisch community we live in.

c) Appropriateness: The basic criterion for all knowledge claims is whether their content is appropriate for or foreign to the community (in German, artgerecht or artfremd). Hence, the epistemic status of a belief is relative to the character of the community. This epistemic criterion demonstrates the ultimate authority in the realm of knowledge: The community itself provides the justificatory standard for the validity of beliefs.

d) Tendency ("Gerichtetheit"): For Nazi philosophers, there was no objective knowledge because no neutral epistemic perspective is available. Baeumler claimed that the "will to knowledge" is always led by current interests and has to have a political tendency. He argued that science without political tendency is idle business and deceit (Baeumler 1934b: 107, 111 
f., 1934c: 154). Krieck's concept of "German Science” is an example of this radical perspectivism: If scientific claims result from the impact of the German character, they rest on a specific attitude. Krieck even regarded natural laws as mere interpretation of the world from a specific racial-völkisch perspective (Krieck 1938: 129). For him, all science is "political science" (Krieck 1936a: 1 ff.).

e) Science as war: Baeumler and Krieck understood science as a war of perspectives. They defined the scientist as a warrior whose activity contributes to the self-realization of his racialvölkisch community. This martial imagery was applied to all levels of scientific activity: Inquiries were depicted as literal struggles with problems (Baeumler 1934b: 112). Epistemic claims have to fight for their validity too. They have to conquer diverging claims within their own epistemic system and opposing claims from epistemic systems of other communities. These inner and outer science wars are part of the general struggle for the realization of a specific racial-völkisch community.

At first sight, this basic picture of Nazi anthropology and its epistemological consequences seems to confirm the assessment of the critical anti-relativists. Nazi ideology sounds like a radical form of relativism that is applied across the board. The relativistic tendency of NS is, however, only the first part of the story. ${ }^{\mathrm{xi}}$ This is because Nazi philosophers rejected the label relativism fiercely. They regarded relativism as a fundamental problem of modern societies and presented NS as the long overdue political solution of said problem. Take, e.g., Rosenberg who characterized the idea of the "relativity of the universe" as an "illness of our time" that was overcome by the "organic truth of NS" (Rosenberg 1938: 694). This "illness" was often characterized as a heritage of the nineteenth century for which intellectual tendencies such as individualism, liberalism, historicism, and pragmatism were responsible. ${ }^{\mathrm{xii}}$ Moreover, relativism was considered as a result of the "decomposing" (zersetzend) impact of the "Jewish spirit." xiii This dismissal raises important interpretative questions regarding the relation of NS and relativism. In the following, I argue that Nazi philosophers had historical, political, and systematic reasons to reject relativism. Their anti-relativistic convictions expose the weakness of the received view of NS as relativism.

In the late nineteenth and early twentieth centuries, relativism was often presented as a dangerous consequence of the modern spirit. The societal changes of modernity and the insights into the historical plurality of human life were conceptualized as a loss of certainty. Construed as dissolution of fixed values, these relativistic tendencies seemed to bring about anarchy and nihilism (See, e.g. Windelband 1884: 116 f., Dilthey 1898). Note that this common usage of relativism could have an anti-Semitic connotation. ${ }^{\text {xiv }}$ Nazi philosophers thus 
had historical and political reasons to consider relativism as a problem that has to be overcome. But there were also systematic reasons to reject relativism from a Nazi perspective. Note that Nazi ideology was a racist anthropology. Nazi philosophers believed in an objective hierarchy of races and attempted to justify their ranking. The conviction that there is a "master race" (Herrenrasse) and that its superiority can be demonstrated is the non-relativistic core of Nazi ideology. Nazi philosophers did not advocate tolerance of other ways of life or keep neutral when being confronted with different worldviews. They ranked the cultural systems of other communities without qualification and deduced a claim to power from their ranking. Moreover, the "Nordic race" was often characterized as the only race whose communities possess the "creative strength" to develop culture. Hence, all cultural goods including morality, science, and philosophy were defined as achievements of "Nordic" communities. Here truth and objectivity entered the picture again because they were defined as distinct values of the "master race." Krieck claimed straightforwardly: "Slaves do not know truth." (Krieck 1938: 125) He did not think that "slaves" have their own truth. On Krieck's view, they simply lack the intellectual and moral capacities to develop true insights. ${ }^{\mathrm{xv}}$

These non-relativistic assumptions of Nazi racism reveal a fundamental tension: On the one hand, Nazi philosophers rejected universal aspirations and absolute claims. Their emphasis on the dependence of values, knowledge, and truth on the "racial-völkisch" community is a radical form of relativization. Hence, Nazi ideology is characterized by a relativistic tendency. On the other hand, Nazi philosophers rejected relativism as well. They were convinced that there is a hierarchy of races and believed in an objective justification of their ranking. By defining truth and objectivity as distinct values of the master race, their nonrelativistic features should be saved.

Most Nazi philosophers were aware of this tension and thus argued that NS overcomes the opposition between relativism and absolutism. They claimed that the Nazi worldview is tantamount to a third way in philosophy that is neither absolutist nor relativistic. Their argumentative strategies always referred back to the alleged special character of their framework of relativization: the "racial-völkisch" community. ${ }^{x v i}$ Nazi biologists argued that that race is an objective concept that can be researched scientifically. Here the reduction of knowledge to the racial-völkisch framework could be regarded as non-relativistic because it revealed the natural foundation of all knowledge claims, i.e. the racial types as well as their ranking (see Danneberg 2013: 157-162). This racist version of a naturalistic epistemology remained an often-invoked promise: The results of the "racial science" were rather poor and 
did not meet the high expectations of scientists, philosophers, and politicians (see Koonz 2003: 190-220).

Nazi thinkers thus developed alternative strategies to justify their racism. In particular, cultural arguments to underpin the racist hierarchy became more and more important. The political anthropology of Rosenberg, Baeumler, and Krieck provided an evaluative framework that could be applied to the philosophical problem of relativism as well. According to Rosenberg, the property of race is tantamount to the essence of humans that distinguishes them fundamentally from the animal world. He used the term "race-soul" (Rassenseele) to signify the deep, spiritual unity of human groups that cannot be found in nature. Rosenberg thus regarded a specific disposition as the essence of humanity: the capacity to develop a collective identity. Yet, he did not think that all humans possess a "race-soul." Rosenberg was convinced that only the "Nordic race" enables its members to create particular communities and hence to develop "Völkisch personalities" (völkische Persönlichkeiten) (Rosenberg 1938: 249). Here, selfhood became the most important criterion to assess the value of a community: the more a community knows, realizes, and expresses itself, the better this community is. Thus, it is the relationship to themselves that constitutes the superiority of these communities. Rosenberg regarded this particularist disposition as a prerequisite of cultural development. He thought, again like many of his fellow Nazi philosophers, that, in the contemporary world, only the Germans are capable of the deliberate particularism that marks the peak of humanity.

On this version of Nazi ideology, particularism becomes the standard to assess the value of a community and its cultural systems. This evaluative standard holds for epistemology too. From a Nazi perspective, epistemic systems can be ranked according to their expression of the "racial-völkisch" essence of the world: the more particularist an epistemic system is, the more it corresponds to true reality of humanity (see, e.g. Krieck 1937: 33f., 1938: 130). Universal views, on the other hand, do not capture the racial order of the world at all and are thus “degenerate" ideas (see, e.g. Baeumler 1937d: 126 f.). This line of thought offers a rationale within Nazi anthropology to argue that their particularist epistemology is neither relativistic nor absolutist. Nazi philosophers could argue that the insight into the "racial-völkisch" relativity of knowledge claims constitutes an epistemic privilege. This view is superior because a specific community develops a view that holds for all other communities too and, hence, is not relativistic. But since not all communities are capable of developing the insight into the relativity of all knowledge claims, this view is neither absolute nor universal. Even the understanding of epistemic particularism is restricted to certain groups of people. Yet, this argument restricts only the availability of epistemic particularism. The general validity and 
alleged superiority of this view remains in tension with the relativistic tendency of its actual content. Remember the key motifs of the epistemologies of Baeumler and Krieck such as limitation or appropriateness.

To sum up, Nazi philosophers developed various strategies to present their approaches as overcoming the opposition between absolutism and relativism. While their critique of absolutism has strong relativistic tendencies, their rejection of relativism is based on the nonrelativistic core of their racism. Both aspects are an essential part of the self-understanding of Nazi philosophers despite the inner tensions of this position. These tensions could never be removed entirely. When we look at the critique of absolutism, NS seems to be a radical kind of relativism. When we consider the racist core of Nazi ideology, we find strong nonrelativistic assumptions. Thus, Nazi philosophers often simply claimed that NS makes the debate over absolutism and relativism redundant (e.g., Baeumler 1943b: 196 f., Krieck $1935 b)$.

Nevertheless, the ambition to overcome the opposition between absolutism and relativism connected the ideological discussion with broader philosophical debates. Moreover, the promise to solve the problem of relativism in a new way was a main reason why philosophers considered NS as a political option in the historical context. The argument equating NS with relativism is thus a main hindrance to critically examining the philosophical collaboration with the Nazi regime. I turn to this topic in the next section.

\section{The Academic Debate: The Prize Question of the Prussian Academy of Science}

Relativism was also a much-discussed philosophical issue in the academic debates during NS. In 1936, the historical-philosophical class of the Prussian Academy of Sciences announced a prize question on the topic: "the inner reasons of philosophical relativism and the possibility of its overcoming."xvii This prize question was launched by Nicolai Hartmann (1882-1950) and supported by his colleague Eduard Spranger (1882-1963). Both held chairs in philosophy at the University of Berlin. Hartmann was one of the leading German philosophers in the early twentieth century and developed a new approach to ontology. He neither engaged in a philosophical justification of NS nor in direct political activities. Yet, Hartmann stayed loyal to the Nazi regime and participated in representative academic projects. He organized the philosophical contribution to the well-known Aktion Ritterbusch which was meant as a "war deployment of humanities" (Kriegseinsatz der Geisteswissenschaften). Moreover, Hartmann was a member of the German Philosophical 
Association (Deutsche Philosophische Gesellschaft) since 1917. Founded by Bruno Bauch (1887-1942) after his break with the Kant Society (Kant Gesellschaft) in 1917, the DPG pursued a nationalist and racist agenda in philosophy. ${ }^{\text {xviii }}$

The prize question of 1936 was also a prestigious project, not least because of its politically explosive topic. Spranger later claimed that Hartmann proposed this topic because he too was concerned that the time was "already very corroded by the illness of relativism" (Spranger 1960: 442). ${ }^{\text {xix }}$ There were eight anonymized submissions. The prize was awarded to Eduard May (1905-1956) at the Leibniz Day of the Prussian Academy of Science in 1939. The committee also praised Johannes Thyssen's (1892-1968) study Das Problem des Relativismus (The Problem of Relativism). Thyssen was an associate professor at the University of Bonn where he was also appointed as full professor in 1947. May habilitated with his prize-winning study Am Abgrund des Relativismus (At the Abyss of Relativism) at the University of Munich in 1942. He was originally a biologist and turned to philosophy under the influence of Hugo Dingler's (1881-1954) philosophy of science. During NS, he worked as a scientist in the concentration camp Dachau and later, because of his expertise in pest control, in the concentration camp Auschwitz. May was, however, never member of a party organization of the NSDAP. He could establish himself in academic philosophy after 1945 and was appointed as full professor at the Free University Berlin in 1951 (see Hoyer 2005, Klee 2005: 398).

Since Hartmann was disappointed by the outcome of the prize question, he convinced his assistant Hermann Wein (1912-1981) to engage with the problem of relativism. Wein's habilitation The Problem of Relativism was published in the volume Systematic Philosophy (1942), alongside prominent representatives of contemporary German philosophy such as Arnold Gehlen (1904-1976) and Rothacker. The edition of this volume was Hartmann's contribution to the Aktion Ritterbusch. Wein followed Hartmann from Berlin to Göttingen in 1945 and was appointed as außerplanmäßiger (extraordinary) professor after the death of Hartmann in 1950. He published a second edition of his relativism study in 1950 and changed all politically incriminating passages. In later bibliographies he mentioned only the edition of 1950 as publication of his habilitation (for details on Wein see Tilitziki 2002: 863-867).

What did academic philosophers think about relativism? Let us start with the set-up of the prize question itself: The prize question introduces a broad concept of relativism and attributes problematic consequences to this position. Any view that relativizes truth is defined as philosophical relativism. Since relativism has a "decomposing" (zersetzend) impact on philosophy and science, its emergence is considered as an epistemological problem that has to 
be overcome. The prize question suggests that every solution to the problem of relativism presupposes an insight into its "inner reasons". These "inner reasons" are specified as "hidden presuppositions" (stillschweigende Voraussetzungen) that are shared by all forms of relativism and that indicate problems of philosophy in itself. Thus, relativism is regarded as the opposite of philosophy proper (see Thyssen 1955: XIV f.).

How did academic philosophers respond to this question? May's prize-winning study (a) and Wein's follow-up study (b) show us the general tendency of the academic approaches and enables us to define the relation of the academic discussion to the ideological debates:

a) May identified the problem of relativism with the problem of truth in itself. $\mathrm{He}$ introduced a correspondence theory of truth and claimed that common sense, the ordinary practice of the most advanced empirical sciences and proper metaphysics presuppose this concept of truth. Moreover, he argued that any inquiry has to acknowledge specific epistemic values, namely clarity and consistency, to be in accordance with the logical core of truth: the law of non-contradiction. May defined disagreement as both the most important source of contradictions and the motivation for relativism. The relativist holds, according to May, that the two parties of a genuine disagreement can be equally right. Because of this deliberate violation of the law of non-contradiction, relativism is in opposition to truth and, hence, a threat to any form of knowledge.

May also tells us a well-known story about the emergence of modern relativism: $\mathrm{He}$ believed that the rise of empiricism in the nineteenth century caused the decay of the apriori and, therefore, relativism emerged. He claimed that empirical experience is not sufficient to overcome disagreement, not even in the natural sciences. The pursuit of truth has to be lead by a "meta-empirical, but nevertheless reality-rooted standard" (überempirischer aber dennoch wirklichkeitsverankerter Maßstab; May 1941, 136). May thought: "The only anchor in the chaos of experience is [...] the apriori." (154). His proposal for a solution to the problem of relativism was thus a new apriorism. He claimed that our "immediate lived experience" (unmittelbares Erlebnis) of mind-independent facts involves "proper apriorities" (268). May believed that our basic experience of sensory qualities such as colors has to be understood as "experiential grasping of a priori concepts" (erlebnishaftes Erfassen apriorischer Begriffe; 237). The exposition of this new apriorism remained, however, sketchy.

Note that May dedicated the conclusion of his study to the clarification of the ideological standing of his position. He admitted that he defended a core principle of rationalism: the absolute concept of truth. But he highlighted that his approach was distinct from any form of Enlightenment and, moreover, opposed empiricism and positivism. May also stated that his 
view could be seen as being in conflict with the philosophy of Krieck who was one of the fiercest rivals of his mentor Dingler. May emphasized that he agreed with Krieck's emphasis on the "völkisch-racial relativity" of knowledge acquisition (294). But he rejected any attempt to relativize the validity of truth and knowledge to specific entities. Here May noted correctly that Krieck sought to preserve truth and objectivity as epistemic privileges of the master race. He thus concluded that his position was not in conflict with Krieck, although he proposed that Krieck should clarify his view on the problem of validity. This is because some pupils of Krieck repudiated any quest for absolute truth and objective knowledge. May emphasized that he disagreed only with such radical views (295-297).

b) When we look at Wein's case, the connection between the academic discussion and the ideological debate becomes even clearer. Wein did not develop a philosophy of NS, although he was a member of the NSDAP since 1937 and worked for the so-called Amt Rosenberg (Rosenberg office), which was responsible for ideological surveillance and education. Baeumler was a referee of Wein's habilitation and criticized the study fiercely. He assumed that his approach to the problem of relativism was motivated by opportunism (see Baeumler 1942). This assessment suggests that Wein's contribution shows us what Nazi philosophers wanted to hear about relativism during NS.

Wein presented relativism as a comprehensive problem that had to be overcome in all areas of life. His study emphasized the "evil" sources and "terrifying" consequences of relativism: Wein characterized relativism as a "miscarriage of Enlightenment" (Wein 1942, 530) that flourished in the nineteenth century, especially because of historicism and liberalism (440 f.). The emergence of this "spiritual illness" caused a deep "crisis" that paralyzed the minds of intellectuals and lead to defeatism and nihilism (441-443, see also 457, 459, 495, 539). Wein claimed that the "Jewish spirit" had a natural affinity to "relativistic thinking" (439) and was thus tantamount to a "degeneration of the spirit" (Geist-Entartung; 539).

In contrast to this excessive rhetoric, Wein's systematic argument was rather simplistic. Wein argued that knowledge always consists of a relation between a subject and an object. Relativism follows when you overestimate the subjective part of knowledge and fail to capture the significance of the object. Absolutism follows when you only consider the objective part and neglect the subject. Both totalizing views are false because of their onesidedness (435-37). Wein believed that the Nazi revolution has politically overcome both relativism and absolutism (541). Yet, he did not accept the existing philosophical solutions. Wein did not even mention the ideological proposals of Baeumler and Krieck, and he explicitly rejected the academic proposals of May and Thyssen. Wein's own proposal for 
overcoming both absolutism and relativism remained rather vague. He bombastically called for a new philosophy that considers both the ontological foundation and the anthropological reality of humanity. He emphasized time and again that, on the one hand, human existence is rooted in the "real being of the world" (Sein der Welt überhaupt), but on the other hand, constitutes an independent "structure of being" (Seinsstruktur) in the world (523-526, $558 \mathrm{f}$.) Wein adopted Carl Schmitt's concept Großraumordnung ("great-space-order") and characterized the human relationship to the world as "geistige Großraum-Haltung" ("spiritual great-space-attitude"; 498). But his key concept remained as vague as his anthropological ontology in general.

Both cases suggest the same conclusion: The academic discussion stayed within the framework of the politically accepted discourse and its forms of mutual criticism. The academic contributors refer to Nazi philosophers frequently, use ideological motifs, and often define their relation to the ideological proposals for overcoming relativism. The critical reception of the praised studies of May and Thyssen shows that they were regarded as part of the public discourse. Their proposals were discussed as serious contributions to the general debate on relativism. ${ }^{\mathrm{xx}}$ Later attempts to present these contributions as a hidden critique of the "Nazi relativism of race", as Thyssen does in the preface of the second edition of his study in 1947, are misleading (Thyssen 1947: V). Although Thyssen did not engage in a philosophical justification of NS, he didn't directly criticize Nazi ideology either. Thyssen even admits in the same preface of 1947 that a superficial reader of his study could have concluded, against his alleged intentions, that it conforms to some strands of Nazi ideology. His contribution was read in exactly that way. This only supports my claim that there is a basic conformity between the academic and the ideological debate on relativism during NS. From both perspectives, relativism is considered as a fundamental problem that has to be overcome. Although the academic philosophers remain within the confines of established technical debates, they put forward similar approaches to the problem of relativism to their ideological counterparts. The problem of relativism represents a continuity between Nazi ideology and academic philosophy. This conclusion is supported by Spranger's retrospective reflection in 1960: He claims that the humanities at Humboldt-University succumbed to NS because of their struggle with historicism and their decline into relativism. Nazi ideology presented itself as the ultimate foundation of knowledge claims and, hence, seemed to offer a solution to the problem of relativism (Spranger 1960: $441 \mathrm{f}$.). To sum up, the prize question was an opportunity to show agreement with a leitmotif of Nazi ideology within the bounds of academic philosophy. It is thus a case of philosophical collaboration. 


\section{Conclusion}

This chapter started with a critical examination of the widespread reproach that relativism and NS are connected with each other historically as well as systematically. My investigation of the actual debate on relativism during NS revealed a rather different picture: Nazi philosophers were convinced that their position overcomes the opposition between absolutism and relativism. They developed argumentative strategies to present NS as a third way in philosophy, but could not resolve the tensions between the relativistic tendency and the antirelativistic assumptions of their view. Nevertheless, the general ambition to solve the problem of relativism made their ideology attractive to contemporary philosophers. Anti-relativist sentiments were a strong motivating factor for the philosophical collaboration with NS. Equating NS with relativism hence obscures an important feature of Nazi ideology that partly explains its widespread philosophical acceptance in the historical context.

My chapter also shows that there is a common meaning of relativism in the context of NS. Nazi philosophers, academic philosophers, and Nazi critics share a specific understanding of relativism: They all consider relativism as a fundamental problem that has to be overcome. Relativism is depicted as a vague threat that endangers not only philosophy proper, but society and life in general. It is always the same strands of nineteenth-century philosophy who are found guilty of having caused this problem and the subsequent "crisis" of the modern spirit. Moreover, relativism is only used in a polemical sense: relativists are always the others, the philosophical and/or political enemies. To label someone a relativist is almost tantamount to making him an enemy. This common politics of relativism can be summarized by adopting the title of Käte Friedemann's (1932) article on this topic: The specter of relativism (Das Gespenst des Relativismus) haunts the context of NS. To banish this specter is a prerequisite for a less prejudiced and more effective critique of Nazi ideology and its ties to the philosophy of the early twentieth century.

\section{Acknowledgement}

This work was supported by the European Research Council (ERC) under Grant 339382. For critical comments and helpful suggestions, I am indebted to audiences in Vienna and Frankfurt a. M., as well as to my co-editors. 


\section{Literature}

Apel, K.-O. (1988), “Zurück zur Normalität? Oder könnten wir aus der nationalen

Katastrophe etwas Besonderes gelernt haben? Das Problem des (welt-)geschichtlichen Übergangs zur postkonventionellen in spezifisch deutscher Sicht,” in W. Kuhlmann (ed.) (1988) Zerstörung des moralischen Selbstbewußtseins: Chance oder Gefährdung?, Frankfurt a. M.: Suhrkamp, 91-142.

Baeumler, A. (1934a), "Der Sinn des großen Krieges”, in: Männerbund und Wissenschaft, Berlin: Junker und Dünnhaupt, 1-29.

—(1934b), "Die geistesgeschichtliche Lage im Spiegel der Mathematik und Physik," in Männerbund und Wissenschaft, 75-93

—(1934c), "Der theoretische und der politische Mensch," in Männerbund und Wissenschaft

S. $94-138$

—(1934d), "Der politische Student," in Männerbund und Wissenschaft, 149-156.

—(1937a), "Rosenberg der Ghibelline,”, in Politik und Erziehung, Berlin: Junker und Dünnhaupt, 16-28

-(1937b), "Der politische Volksbegriff," in Politik und Erziehung, 43-49.

—(1937c), "Der Kampf um den Humanismus," in Politik und Erziehung, 57-66.

—(1937d), “Kultur und Volk. Die Begründung der deutschen Leibesübungen”, in Politik und Erziehung, 123-138.

—(1942), Gutachten zur Habil.-Schrift Wein, Archive, Humboldt-University Berlin, Kur. W 93, PA Wein.

—(1943a), "Nationalsozialismus und 'Idealismus," in Bildung und Gemeinschaft, $2^{\text {nd }}$ ed., 86-97.

—(1943b), "Philosophie", in Bildung und Gemeinschaft 196-198.

—(1943c), Weltdemokratie und Nationalsozialismus, Berlin: Dunker \& Humblot.

—(1943d), Alfred Rosenberg und der Mythos des 20. Jahrhunderts, München: Hoheneichen.

Bauch, B. (1934/35), “Wert und Zweck,” Blätter für Deutsche Philosophie VIII: 39-59.

Böhler, D. (1988), “Die deutsche Zerstörung des politisch-ethischen Universalismus. Über die Gefahr des - heute (post-) modernen - Relativismus und Dezisionismus”, in Kuhlmann (1988), 166-216. 
Böhnigk, V. (2016), “Eine Beziehung zwischen Relativismus und Nationalsozialismus Tatsache oder Fiktion?" Jahrbuch zur Geschichte und Wirkung des Holocaust 20: 243-262.

Danneberg, L. (2013), Wissenschaftsbegriff und epistemischer Relativismus im Nationalsozialismus, url: http://fheh.org/wp-content/uploads/2016/07/relativismusld.pdf $(18 / 03 / 16)$.

Del Negro, W. (1942), Die Philosophie der Gegenwart in Deutschland, Leipzig: Felix Meiner.

De Vries, J. (1935a), "Wissenschaft, Weltanschauung, Wahrheit," Stimmen der Zeit 129: 93105.

—1935b, "Rationale oder irrationale Weltanschauung," Stimmen der Zeit 129: 380-392.

Dilthey, W. (1898), "Die Kultur der Gegenwart und die Philosophie,” in Gesammelte Schriften, vol VIII, Göttingen: Vandenhoeck \& Ruprecht, 1962³ , 190-205.

Friedemann, K. (1932), “Das Gespenst des Relativismus,” Philosophisches Jahrbuch 45: 1834.

Hausmann, F.-L. (2007³) “Deutsche Geisteswissenschaft” im Zweiten Weltkrieg: die "Aktion Ritterbusch" (1940-1945), Heidelberg: Synchron.

Herbert, C. (2001), Victorian Relativity: Radical Thought and Scientific Discovery, Chicago: University of Chicago Press.

Kellerwessel, W. (2014), "Universalism and Moral Relativism: On Some Aspects of the Modern Debate on Ethics and Nazism," in W. Bialas and L. Fritze (eds.), Nazi Ideology and Ethics, Newcastle: Cambridge Scholars.

Köhnke, K.-Ch. (1996), Der junge Simmel in Theoriebeziehungen und sozialen Bewegungen, Frankfurt a. M.: Suhrkamp. 
Koonz, C. (2003), The Nazi Conscience, Cambridge, Mass.: Harvard University Press.

Krieck, E. (1934), Wissenschaft, Weltanschauung, Hochschule, Leipzig: Armanen-Verlag. - $\left(1936 \mathrm{a}^{20}\right)$, Nationalpolitische Erziehung (1932), Leipzig: Armanen-Verlag.

-(1936b), Völkisch-politische Anthropologie, vol. 1, Leipzig: Armanen-Verlag.

—(1935a), "Ist der Nationalsozialismus 'universalistisch'?" Volk im Werden 3: 184-186.

—(1935b), "Jesuitischer Relativismus," Volk im Werden 3: 316-319.

-(1937), Völkisch-politische Anthropologie, vol. 3, Leipzig: Armanen-Verlag.

—(1938), Völkisch-politische Anthropologie, vol. 3, Leipzig: Armanen-Verlag.

Kroll, F-L. (1998), Utopie als Ideologie. Geschichtsdenken und politisches Handeln im Dritten Reich, Paderborn: Schöningh.

Lieber, H.-J. (1966), “Die deutsche Lebensphilosophie und ihre Folgen,” in Freie Universität Berlin (ed.), Nationalsozialismus und die deutsche Universität, Berlin: De Gruyter, 92-108.

Lukàcs, G. (1954), Die Zerstörung der Vernunft. Der Weg des Irrationalismus von Schelling zu Hitler, Berlin: Aufbau.

May, E. (1941), Am Abgrund des Relativismus, Berlin: Lüttke.

Klee, E. $\left(2005^{2}\right)$, Das Personenlexikon zum Dritten Reich, Frankfurt a. M.: Fischer.

Meyers Lexikon $\left(1942^{8}\right)$, vol. 9, Leipzig: Bibliographisches Institut.

Raphael, L. (2014), "Pluralities of National Socialist Ideology. New Perspectives on the Production and Diffusion of National Socialist Weltanschauung", in , M. Steber and B. Gotto (eds.), Visions of Community in Nazi Germany. Social Engineering and Private Lives, Oxford: Oxford University Press, 73-86.

Rosenberg, A. (1934), Krisis und Neubau Europas, Berlin: Junker und Dünnhaupt.

-(1935), "Die Weltanschauung in der Außenpolitik", in Gestaltung der Idee. Blut und Ehre Bd. II, München: Franz Eher, 1939 ${ }^{10}$, 246-262.

-(1938), Der Mythus des 20. Jahrhunderts (1930), $125^{\text {th }}-128^{\text {th }}$ ed., München: Hoheneichen. 
Sandkühler, H. J. (2009), Philosophie im Nationalsozialismus, Hamburg: Felix Meiner.

Sieg, U. (2013), Geist und Gewalt. Deutsche Philosophen zwischen Kaiserreich und Nationalsozialismus, München: Carl Hanser.

Spranger, E. (1960), “Das Historismusproblem an der Universität Berlin seit 1900,” in Gesammelte Schriften, vol. 5, Tübingen: Max Niemeyer, 1969, 430-446.

Sluga, H. (2013), Heidegger's Crisis: Philosophy and Politics in Nazi Germany, Cambridge, Mass.: Harvard University Press.

Szeynmann, C.-Ch. (2013), "Nazi Economic Thought and Rhetoric During the Weimar Republic: Capitalism and its Discontents,” Politics, Religion \& Ideology 14: 355-376.

Steizinger, J. (2016), "Politik versus Moral. Alfred Baeumlers Versuch einer philosophischen Interpretation des Nationalsozialismus," Jahrbuch zur Geschichte und Wirkung des Holocaust, vol 20, 29-48.

- (2017), "Reorientations of Philosophy in the Age of History: Nietzsche's Gesture of Radical Break and Dilthey's Traditionalism,” Studia philosophica 76: 223-244.

- (2018), “The Significance of Dehumanization: Nazi Ideology and its Psychological Consequences," Politics, Religion \& Ideology 19: 1-19.

Tilitzki, Ch. (2002), Die deutsche Universitätsphilosophie in der Weimarer Republik und im Dritten Reich, Berlin: De Gruyter.

Tugendhat, E. (2009), "Der moralische Universalismus in Konfrontation mit der NaziIdeologie," Jahrbuch zur Geschichte und Wirkung des Holocaust 13: 61-75.

Thyssen, J. (1941), (1947²), (1955³), Der philosophische Relativismus, Bonn: Ludwig Röhrscheid.

Wein, H. (1942), “Das Problem des Relativismus,” in N. Hartmann (ed.) Systematische Philosophie, Stuttgart and Berlin: Kohlhammer, 431-559. 
Windelband, W. (1884), "Kritische oder Genetische Methode”, in Präludien. Aufsätze und

Reden zur Philosophie und ihrer Geschichte, vol. 2, Tübingen: Mohr, 1915 , 99-135.

\author{
Wolin, Richard 2004, The Seduction of Unreason: The Intellectual Romance with Fascism \\ from Nietzsche to Postmodernism. Princeton: Princeton University Press.
}

Wolters, G. (1999), “Der 'Führer' und seine Denker. Zur Philosophie des 'Dritten Reichs,'”

Deutsche Zeitschrift für Philosophie 47: 223-251.

\footnotetext{
${ }^{i}$ There is an intense debate about the question of whether Nazi ideology qualifies as a moral position at all. The examination of this complex issue is beyond the scope of this chapter.

ii All translations are my translations.

iii For careful examinations of Nietzsche's and Dilthey's approach to relativism see Leiter, Kinzel in this volume, see also Steizinger 2017.

iv Weltanschauung (worldview) was a vague concept that connected philosophy and politics in the early twentieth century. The concept captured comprehensive theories about the world that were meant to guide human actions. There was no sharp distinction between philosophy and Weltanschauung: some philosophers considered their philosophy as foundation of a certain worldview and emphasized the political significance of their theories. Others attempted to separate the technical debates of academic philosophy from the popular claims of Weltanschauungsphilosophie (philosophy of worldviews).

The Nazis adopted the concept Weltanschauung from the beginning in order to highlight the comprehensive character of their movement. I call their Weltanschauung an ideology because of its thoroughgoing political nature. Nazi ideologues such as Rosenberg dedicated their whole thinking to develop the Nazi worldview. Nazi philosophers such as Baeumler, Krieck, or Rothacker used their philosophical theories to justify NS. Most of them explicitly developed a philosophy of National Socialism. When I speak of Nazi philosophers, I mean both the ideologues and the philosophers. Academic philosophers engaged, first and foremost, in technical debates and attempted to keep philosophical theory and political practice apart.

${ }^{v}$ The Nazi government was characterized by various circles of power who competed with each other for political influence (see Kroll 1998: 19 f.).

${ }^{v i}$ For examples see Sluga 1993, Wolters 1999, Sandkühler 2009, Sieg 2013. The research on philosophy during National Socialism is focused on Martin Heidegger. Since his case is not exceptional from a historical point of view, I concentrate on lesser known philosophers who collaborated with NS at least for some time.

vii For details about Rosenberg's role and views see Kroll 1998, Steizinger 2018.

viii For this line of thought see, e.g. Baeumler 1934b: 92 f. 1937b, 1937c, 1943c, Krieck 1937: 8 f., 1938: 2528, Rosenberg 1934: 8 f., 1935, 1938: 639 ff., $671 \mathrm{f}$.

ix See, e.g. Baeumler 1937d: 126 f., 1943c, 1943d: 96 f., Rosenberg 1935, 1938: 33, 81 f., 84 f., 105,106 f. 479 f., 482 f.; Krieck 1936b: 42-44, 1935a, 1937: 45-37, 1938: 119 f.

x In German: "Deutsche Wissenschaft ist nichts anderes als Ausdruck, Auswirkung deutscher Art und Wesenheit."

${ }^{x i}$ Böhnigk (2016) denies that National Socialism has a relativistic tendency and emphasizes its universal aspirations against the critical anti-relativists. He ignores, however, the Nazi critique of universalism and downplays their commitment to racial particularism. Moreover, Böhnigk identifies Nazi ideology with biological racism and thus misses its general character.

xii See, e.g. Rosenberg 1938: 694 f., Baeumler 1943d: 27 f., 67 ff., Bauch 1934/35: 43 f., 50 f., 52, Del Negro: 10-13, Krieck 1936a: 3, 7 f., 1938: 11.

xiii See, e.g. Bauch 1934/35: 43 f., 53 f., Del Negro 1942: 11-13, 42 f., Krieck 1934a: 16 f. The popular Meyers Dictionary of 1942 defines relativism as the spiritual attitude that represents the modern liberalindividualistic perplexity and lack of principles. Jews occupy this position because of their disposition, and intentionally for the purpose to decompose society (Meyers Lexikon 1942: 290). Another example is the Nazi critique of Einstein's theory of relativity (see Herbert 2001: 12-14, 213 Danneberg 2013: 74 ff).
} 
xiv See, e.g. Köhnke (1996: 476-478), who shows the anti-Semitic connotations of the early reception of Simmel's relativism. Simmel is also the prime example of the decomposing relativism of the "Jewish spirit" in Del Negro's Nazi account of contemporary philosophy (Del Negro 1942:11 f., 42 f.). For a careful account of Simmel's relativism and its diverse reception see Kusch, this volume.

${ }^{\mathrm{xv}}$ For this line of thought see esp. Rosenberg 1938: chapter I, VI; see also, e.g. Baeumler 1934c, 1937a, Krieck 1936b: 60 f., 1937: 46-48, 1938: 130 f. For a detailed account of Baeumler's racist particularism see Steizinger 2016. Because of the racist core of their ideology, Nazi philosophers cannot be seen as defenders of the "plurality of Völker and cultures" (Tilitzki 2002: 29). Tilitzki's broad study contains much intriguing material but develops an untenable and unacceptable reading of Nazi ideology.

xvi See, e.g. Baeumler 1942, 1943b: 197, Krieck 1936b: 16 f., 1935: 318 f., 1937: 33f, 1938: 11.

xvii In German "Die inneren Gründe des philosophischen Relativismus und die Möglichkeit seiner

Überwindung." Danneberg (2013) addresses the prize question in his extensive reconstruction of the attempts of Nazi scientists and philosophers to develop new standards of epistemic validity.

xviii Schefczyk and Kuchinsky (2016) give a convincing account of Hartmann's ambivalent role during

National Socialism. For the political orientation of the DPG see Sluga 1995, Sieg 2013. For the significance of the Aktion Ritterbusch see Hausmann 2007.

xix In German: "von der Krankheit des Relativismus schon stark angefressen."

${ }^{\mathrm{xx}}$ For a summary of the critical reception of May's and Thyssen's studies see Danneberg 2013: $441 \mathrm{ff}$. 